\title{
Pharmacokinetics of 5-aminosalicylic acid enteral suspension in Crohn's disease patients and normal volunteers
}

\author{
CN WILLIAMS, FRCPC, FACP, FACG, E MORGAN, FRCPC
}

\begin{abstract}
Aminosalicylic acid (5-ASA) is available in many countries in tablet, enema and suppository form. A new enteral suspension was studied in six patients with Crohn's disease affecting the upper gastrointestinal tract and in six healthy volunteers. Four grams of 5-ASA dissolved in $240 \mathrm{~mL}$ suspension was given via a nasoduodenal tube over $4 \mathrm{~h}$. Blood was drawn at $0,1,2,3,4,5,6,7$, 8,12 and $24 \mathrm{~h}$, and $24 \mathrm{~h}$ urine and stool were collected for 5-ASA and $n$-acetyl-5-ASA analyses. All patients and subjects tolerated the procedure without problems and no side effects were encountered. All subjects and volunteers had normal renal function before and after the study; serum creatinine and blood urea nitrogen did not change. Urine recovery of 5-ASA ranged from 0.6 to $3.4 \mathrm{~g}$ (controls) and 0.46 to $3.6 \mathrm{~g}$ (patients). Stool recovery of 5 -ASA was 0.1 to $0.3 \mathrm{~g}$ (controls) and 0.12 to $0.54 \mathrm{~g}$ (patients). There was delayed absorption of 5-ASA in patients compared to controls, shown by time to peak concentrations $(4$ to $6 \mathrm{~h}$ versus $3 \mathrm{~h}$ ). Predominantly urine excretion of the $n$-acetyl metabolite occurred in both groups, with less than $12 \%$ stool excretion. Continued treatment induced remission. An enteral suspension of 5-ASA may be of benefit in selected patients with proximal small bowel Crohn's disease. Can J Gastroenterol 1990;4(7):458-462 (pour résumé, voir page 459)
\end{abstract}

Key Words: 5-Aminosalicylic acid, Pharmacokinetics Scotia

Victoria General Hospital and Department of Medicine, Dalhousie University, Halifax, Nova

Correspondence and reprints: Dr CN Williams, Division of Gastroenterology, Department of Medicine, Dalhousie University, 5849 University Avenue, Halifax, Nova Scotia B3H IW2.

Telephome (902) 494-2333, Fax (902) 494-1624
5-AMINOSALICYLIC ACID (5-ASA) IS the active principle of sulphasalazine $(1,2)$, widely used in the treatment of patients with inflammatory bowel disease (IBD). 5-ASA, which acts locally, is available for treatment of these disorders in tablet, enema and suppository form. Tablets are designed to deliver the agent directly to the site involved. Tablets are coated with different resins of varying thicknesses, which prevent acid denaturization and present the drug intact to the intestine, where it is released in the distal small bowel (3). By varying the type of coating and its thickness, it is believed that release can be targeted to specific parts of the small bowel.

One preparation has an ethylcellu. lose coating with 5-ASA microgranules designed for release in the upper small bowel (4). A second major type of 5-ASA preparation is that bound to a pro-drug. Sulphasalazine is the first ex- 
Pharmacocinétique de la solution entérale d'acide

5 -aminosalicylique administrée aux patients porteurs de malade de Crohn et aux volontaires en bonne santé

RESUME: L'acide 5-aminosalicylique (5-ASA) est en vente dans de nombreux pays sous forme de comprimés, de lavements et de suppositoires. Une nouvelle solution entérale a été étudiée chez six patients atteints de maladie de Crohn impliquant les voies digestives supérieures et chez six volontaires en bonne santé. Une suspension de $240 \mathrm{~mL}$ contenant $4 \mathrm{~g}$ de 5 -ASA a été administrée par sonde nasoduodénale sur quatre heures. On a effectué des prélèvements sanguins à 0 , $1,2,3,4,5,6,7,8,12$ et 24 heures. On a recueilli l'urine et les selles à 24 heures afin de procéder à l'analyse du 5 -ASA et du $n$-acétyl-5-ASA excrétés. Tous les participants ont subi la procédure sans problèmes ni effets secondaires. La fonction rénale de tous était normale avant et après l'étude; la créatinine sérique et l'azotémie n'ont pas changé. Le 5-ASA excrété dans l'urine variait de 0,6 à 3,4 $\mathrm{g}$ (contrôles) et de 0,46 à $3,6 \mathrm{~g}$ (patients). Le 5-ASA excrété dans les selles était de $0,3 \mathrm{~g}$ (contrôles) et de 0,12 à $0,54 \mathrm{~g}$ (patients). Le temps du pic de concentration dénote l'absorption retardée du 5-ASA chez les patients par rapport aux contrôles ( 4 à 6 h comparé à $3 \mathrm{~h}$ ). Le métabolite $n$-acétyl est principalement excrété dans l'urine dans les deux groupes, l'excrétion fécale étant inférieure à $12 \%$. La poursuite du traitement a provoqué la rémission. Une solution entérale de 5-ASA peut être bénéfique pour un groupe sélectionné de patients atteints de maladie de Crohn du grêle proximal.

ample of this, 5-ASA being bound to sulphanilamide (5). Olsalazine has two molecules of 5-ASA bound via an azobond and, like sulphasalazine, requires bacterial enzyme action to cleave the azobond and release the 5-ASA. Colonic bacteria contain the necessary enzymes; hence, release is predominantly in the colon or very distal small bowel.

No preparation exists for patients with gastroduodenal or upper jejunal Crohn's disease. It was, therefore, hypothesized that a 5-ASA liquid enema preparation may be suitable for the upper small bowel. The major concern would be increased intestinal absorption and possible renal damage (6-8). Since the introduction of 5-ASA in tablet form, there have been occasional reports of altered serum creatinine, but no published reports of fatal kidney disease have emerged. Current experience includes over 600,000 cycles of treatment over several years. In this experience, six cases of nephritis, possibly related to 5-ASA, have been described - an incidence of $0.01 \%$ (personal communication).

5-ASA undergoes one major metabolic change in humans whereby $n$ acetyl-5-ASA is formed (10). This can occur in the lumen by gut bacterial action in the enterocyte or in the hepatocyte.

This study addresses the following questions: Is 5-ASA enteral suspension safe and effective in patients with upper small bowel Crohn's disease? How much is absorbed and excreted in urine? How much is excreted in stool?

\section{PATIENTS AND METHODS}

Six healthy volunteers (four males and two females) and six patients with Crohn's disease affecting the small bowel gave informed consent. A 10 French nasoduodenal tube was placed via radiological control so that the tip of the tube was lying in the second part of the duodenum. Four grams of 5-ASA in $240 \mathrm{~mL}$ suspension were given over $4 \mathrm{~h}$ into the duodenum. The 5-ASA was provided as an enteral suspension similar to the vehicle used in the 5 ASA enema Salofalk (Interfalk), 164.3 $\mathrm{mOsm} / \mathrm{L}$, with potassium metabisulphite as an antioxidant and sodium benzoate as a preservative. Plasma was collected at $0,1,2,3,4,5,6,7,8,12$ and $24 \mathrm{~h}$ from the start of the infusion, and a $24 \mathrm{~h}$ urine and stool collection was performed. Both 5-ASA and its major metabolite, n-acetyl-5-ASA, were measured by high performance liquid chromatography. All participants underwent urinalysis, hemogram and simultaneous multiple analysis computer screening for liver and renal function before and $24 \mathrm{~h}$ after the 5-ASA duodenal perfusion. In patients who received 5-ASA for seven days or more to treat their upper small bowel disease, urinalysis and blood monitoring of renal function was performed daily.

\section{RESULTS}

There were no changes detected in renal or hepatic function after 5-ASA enteral infusion, and no abnormalities were present on urinalysis. As anticipated, absorption of the 5-ASA enteral suspension was high, with urine recovery varying from 14 to $85 \%$ (Table 1). Stool recovery in volunteers ranged from 0.2 to $12.5 \%$. The time to

\section{TABLE 1}

Urine and stool recovery data of 5-aminosalicylic acid (5-ASA) and n-acetyl-5-aminosalicylic acid (n-ac-5-ASA) in normal volunteers $(\mathrm{g} / 24 \mathrm{~h})$

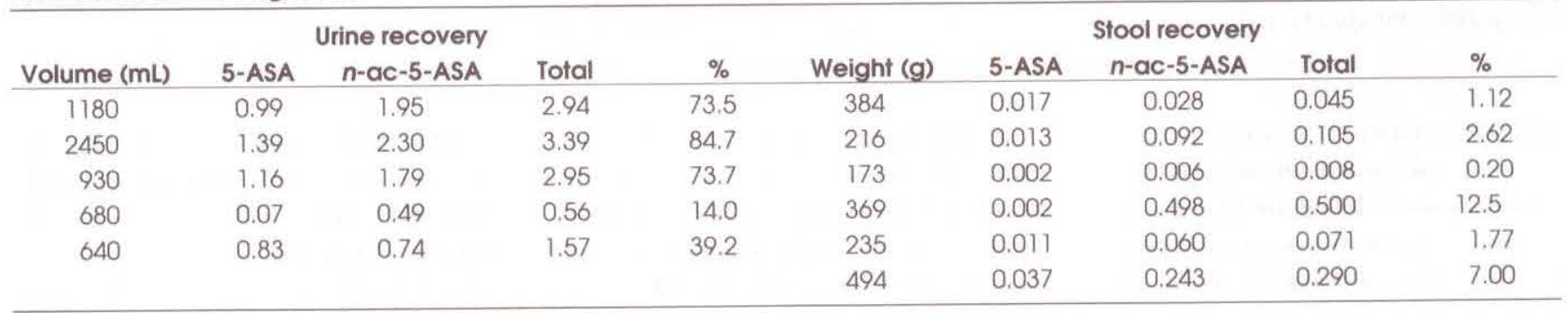




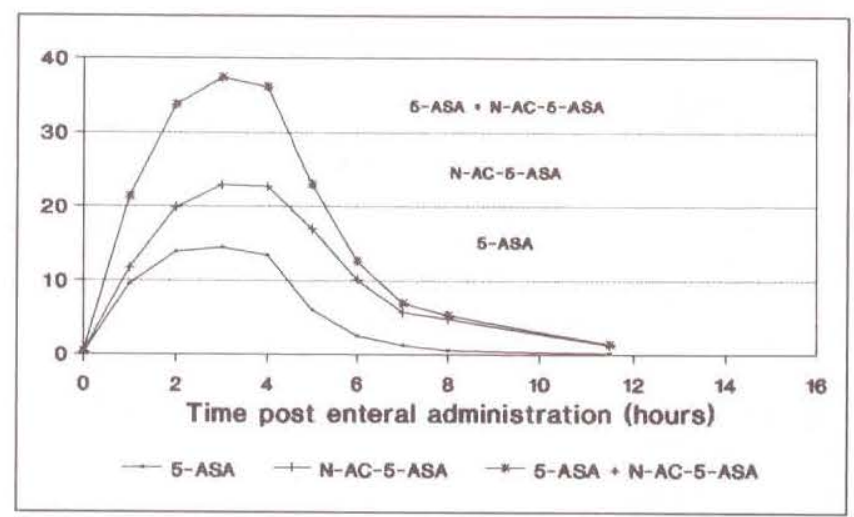

Figure 1) 5-Aminosalicylic acid (5-ASA), n-acetyl-5-ASA (N-AC-5ASA) and total plasma concentrations $(\mu \mathrm{g} / \mathrm{mL})$ in six volunteers after a $4 \mathrm{~g}$ enteral infusion of 5-ASA given over $4 \mathrm{~h}$. The area under the curve for 5-ASA is 63.1 and for n-acetyl-5-ASA is 132.6. The time to peak was $3 \mathrm{~h}$ and the maximum concentration $22.9 \mu \mathrm{g} / \mathrm{mL}$ for $\mathrm{n}$-acetyl-5. ASA

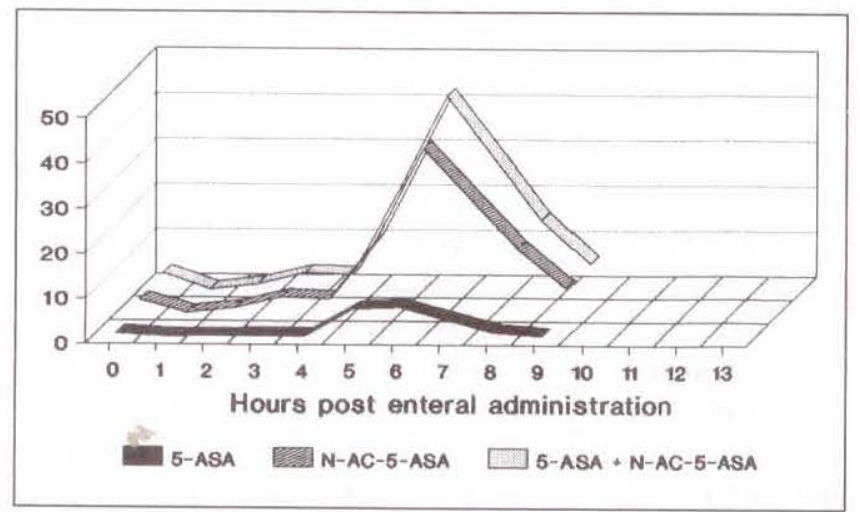

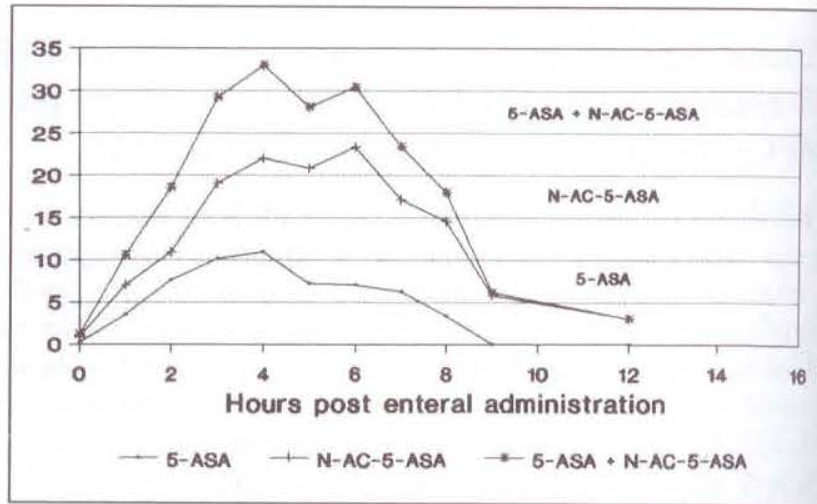

Figure 2) 5-Aminosalicylic acid (5-ASA), n-acetyl-5-ASA (N-AC-5 ASA) and total plasma concentrations $(\mu \mathrm{g} / \mathrm{mL})$ in six patients with Crohn's disease after a $4 \mathrm{~g}$ enteral infusion of 5 -ASA given over $4 \mathrm{~h}$. The area under the curve for 5-ASA is 75.7 and for n-acetyl-5-ASA is 232.6 The times to peak for $\mathrm{n}$-acetyl-5-ASA were 4 and $6 \mathrm{~h}$; the maximum concentrations were 22.0 and $23.4 \mu \mathrm{g} / \mathrm{mL}$, respectively

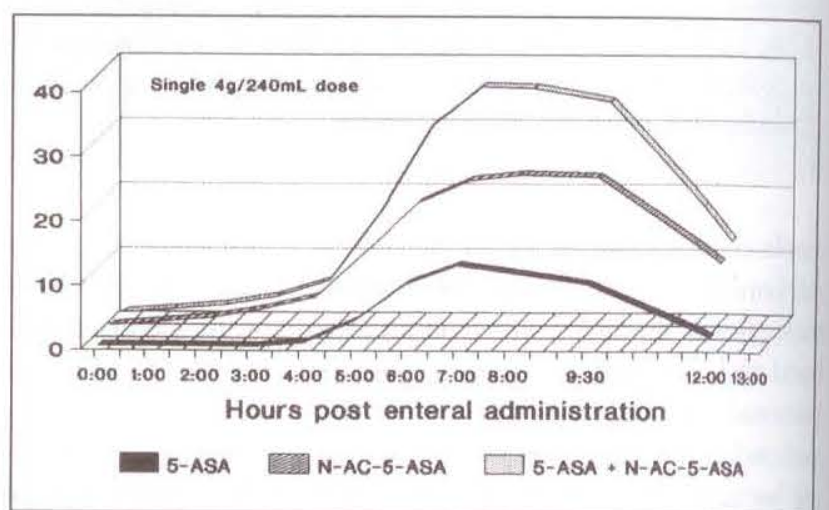

Figure 3) Graph showing delayed absorption in patient EM (left) (time to peak $6 \mathrm{~h}$, maximum concentration $36.6 \mu \mathrm{g} / \mathrm{mL}$ ) and in patient $\mathrm{YF}$ (right) (time to peak $8 \mathrm{~h}$, maximum concentration $24.7 \mu \mathrm{g} / \mathrm{mL}$ n-acetyl-5-ASA). 5-ASA 5-Aminosalicylic acid; N-AC-5-ASA n-acetyl-5-ASA
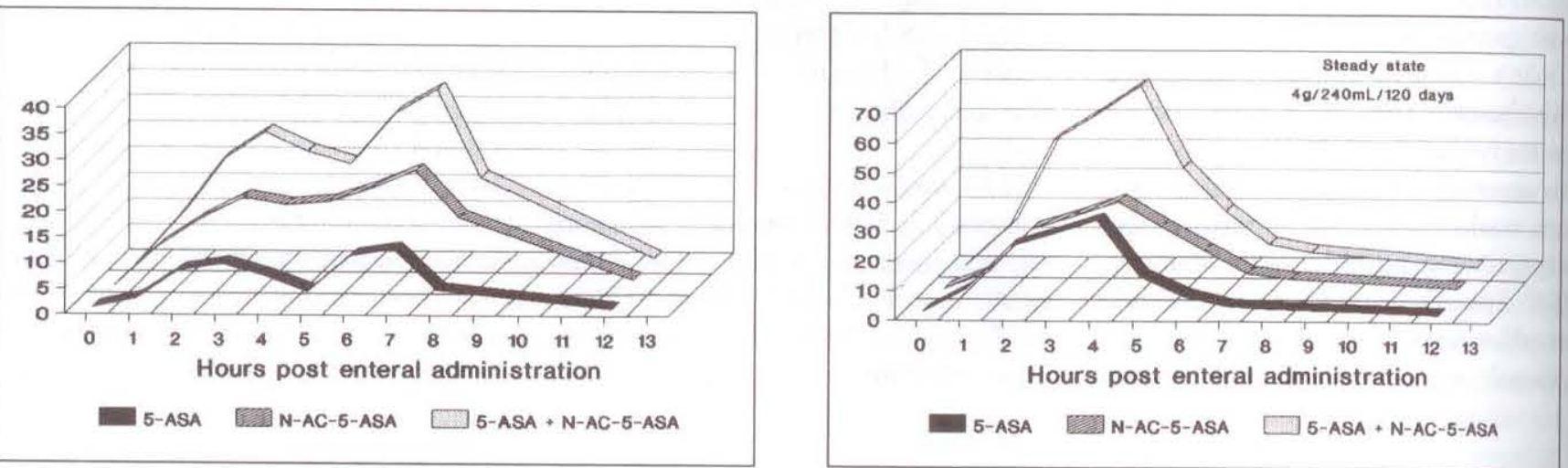

Figure 4) Left Delayed time absorption curve in patient EP (time to peak $7 \mathrm{~h}$, maximum concentration $22.7 \mu \mathrm{g} / \mathrm{mL} \mathrm{n}$-acetyl-5-ASA[N-AC-5-ASAl). After several weeks of $4 \mathrm{~g} 5$-aminosalicylic acid (5-ASA) given enterally over $4 \mathrm{~h}$ daily (right), there was a shortened time to peak of $4 \mathrm{~h}$ and maximum concentration $31 \mu \mathrm{g} / \mathrm{mL}$, for $\mathrm{n}$-acetyl-5-ASA, ie, a return towards the normal pharmacokinetic profile. The area under the curve for 5-ASA was initially $117.3 \mu \mathrm{g} / \mathrm{mL}$, rising to 141 after treatment, for $\mathrm{n}$-acetyl-5-ASA the results are 162.2 and $252.7 \mu \mathrm{g} / \mathrm{mL}$, respectively

peak concentration in serum after 5 . ASA enteral suspension was given to volunteers was $3 \mathrm{~h}$ (Figure 1). This was also true for the major acetylated metabolite and the combination of the two.
The levels were barely detectable $8 \mathrm{~h}$ after administration. In contrast, there was delayed absorption in patients with Crohn's disease, with a double peak at 4 and $6 \mathrm{~h}$ for the acetylated metabolite and the combination $(\mathrm{P}<0.05)$ (Figure 2 ). In two patients there was delayed absorption with a peak occurring at 6 and $8 \mathrm{~h}$ (Figure 3).

Patient EP (Figure 4) is a 56-year- 
TABLE 2

Urine and stool recovery of 5-aminosalicylic acid (5-ASA) and $n$-acetyl ( $n$-ac)-5-ASA in patient EP (g/24 h)

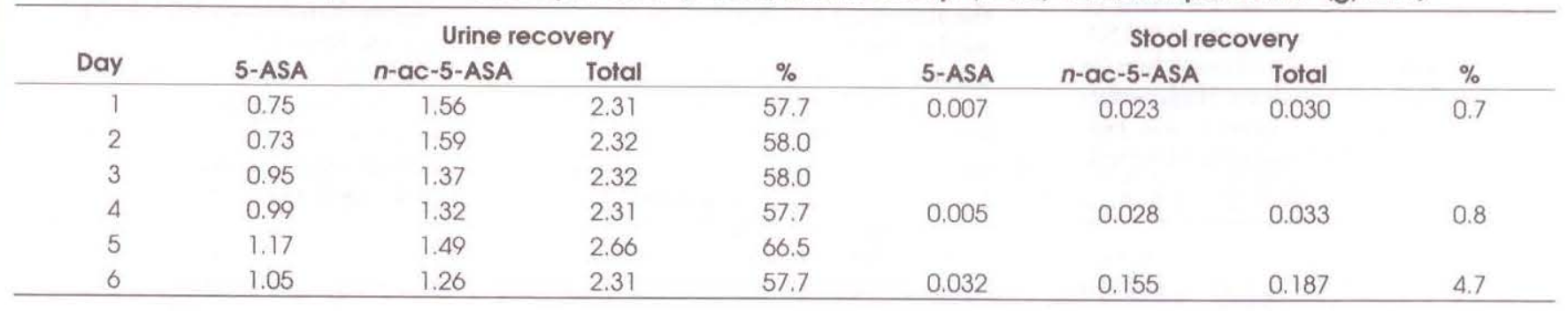

old female with a 16 year history of Crohn's disease. Prior episodes of intestinal obstruction resulted in multiple operations with bowel resection.

An upper gastrointestinal series showed diffuse disease of the whole upper small bowel, apart from the duodenum. Colonoscopy showed no active colon disease. Figure 4 (left) shows the characteristic profile of 5-ASA in the patient's plasma, with the delayed absorption and double peak concentrations. In contrast, after treatment for 10 weeks, the pharmacokinetic profile changed towards that seen in the healthy volunteer group, with an early single peak (Figure 4 [right]). Urine was collected from this patient for six days and steady-state conditions were seen, excretion varying from 57.7 to $66.5 \%$ (Table 2). Representative stool excretion in this patient varied from 0.75 to $4.7 \%$ of the dose given over a five day period. This patient's fasting plasma immediately prior to the daily $n$-acetyl5-ASA infusion was 1.0 and $1.23 \mu \mathrm{g} / \mathrm{mL}$ - in the same range (1.1 to $2.9 \mu \mathrm{g} / \mathrm{mL}$ ) reported after five days in 14 healthy volunteers on Pentasa tablets (Nordic) $1500 \mathrm{mg} /$ day (4). The area under the curve data for the six volunteers and six patients with Crohn's disease are shown in Figures 1 and 2. There is a significant change comparing the patients and the volunteers for both 5-ASA and $n$-acetyl-5-ASA $(\mathrm{P}<0.05)$.

\section{DISCUSSION}

The 5-ASA enteral suspension was well tolerated by the patients with no side effects. The enteral suspension was, in most subjects, well absorbed, with predominantly urine excretion. It appears to be safe; no renal toxicity was seen and no abnormality identified in any blood work relating to the bone marrow, liver or kidneys. In patients who were given a one week course, there was a significant improvement in general well-being, with less abdominal pain, less diarrhea and fewer abdominal cramps. Patient EP, who had multiple small resections for active recurrent Crohn's disease, was admitted with abdominal pain, diarrhea and abdominal swelling and was being considered for further operative treatment. In this patient, total parenteral nutrition followed by enteral nutrition and 5-ASA enteral suspension resulted in a significant remission which has lasted over one year. There is significant delayed absorption in patients with proximal Crohn's disease compared to normal volunteers, and with continued treatment in one patient, absorption returned towards normal.

The worry remains that renal toxicity may be a limiting factor of this form of therapy (6-9). Close monitoring of renal function is an absolute necessity, particularly where long, continued use is contemplated. For reasons of safety, it was decided to give one-week courses of treatment, which was prolonged in only one patient with severely compromised short bowel syndrome with active disease. In this particularly unique situation, the patient obtained a worthwhile benefit from prolonged treatment, not having responded initially to three weeks of either total parenteral nutrition or enteral feeding.

The first pharmacokinetic study of 5-ASA used $150 \mathrm{~g}$ of pure 5-ASA infused rapidly via a nasojejunal tube in four healthy volunteers (11). Peak levels of $n$-acetyl-5-ASA varied from 2.5 to $3 \mu \mathrm{g} / \mathrm{mL}$ at $30 \mathrm{mins}$ to $1 \mathrm{~h}$ and peak levels of 5 -ASA varied from 4.5 to
$9 \mu \mathrm{g} / \mathrm{mL}$. Urinary excretion varied from 46.8 to $69.3 \%$, and fecal excretion from 0 to $3.1 \%$, both in $24 \mathrm{~h}$, a mean of $54 \%$ of the dose being recovered.

One patient's experience with $800 \mathrm{~g}$ uncoated 5-ASA tablets was reported with side effects related to 5-ASA (12). However, blood levels of $n$-acetyl-5ASA in this patient reached a maximum of $6.3 \mu \mathrm{g} / \mathrm{mL} 1.5 \mathrm{~h}$ after dosing, with urinary excretion of $49 \%$ in $48 \mathrm{~h}$. The present controls and patients had peak levels of $n$-acetyl-5-ASA of 22.9 $\mathrm{ng} / \mathrm{mL}$ at $3 \mathrm{~h}$, and $22.0 \mathrm{ng} / \mathrm{mL}$ and 23.4 $\mathrm{ng} / \mathrm{mL}$ at 4 and $6 \mathrm{~h}$, respectively, without symptoms.

The time to peak plasma concentration of $3 \mathrm{~h}$ in the healthy volunteers was unexpected and unexplained. The drug was delivered directly via the nasoduodenal tube to the small bowel for absorption. Peak levels were anticipated at $1.5 \mathrm{~h}$, similar to that seen after pure 5-ASA given to four healthy volunteers (11). The same time to peak was found by Rasmussen (4) using 500 mg Pentasa tablets given orally.

Further studies are indicated in patients with proximal small bowel disease, where results of surgery are poor and where the only agents with proven benefit are corticosteroids and possibly immunosuppressive agents. Azathioprine suffers from the drawback of a mean time to response of 3.1 months, whereas cyclosporine will induce remission within two weeks, but requires close monitoring for toxicity, including renal toxicity. The judicious use of the 5-ASA enteral suspension may be of selective benefit in these difficult to manage patients. Further studies in this selected group of patients are planned, using enteral feeding with or without the use of enteral 5-ASA. 
ACKNOWLEDGEMENTS: The authors acknowledge Léon Gosselin, President of Interfalk Canada Inc for the gift of 5-ASA enteral used in this study, and thank him for arranging the 5-ASA analyses. High performance liquid chromatography was performed by CSauriol of Biopharm, Montreal, Quebec.

\section{REFERENCES}

1. Khan AKA, Piris ], Truelove SC, An experiment to determine the active therapeutic moiety of sulphasalazine. Lancet 1977;ii:892-5.

2. Van Hees PAM, Bakker JH, van Tongeren JHM. Effect of sulphapyridine, 5-aminosalicylic acid, and placebo in patients with idiopathic proctitis: A study to determine the active therapeutic moiety of sulphasalazine. Gut 1980;21:632-5.
3. Dew MJ, Ebden P, Kidwai NS, Lee G, Evans BK, Rhodes J. Comparison of the absorption and metabolism of sulphasalazine and acrylic-coated 5 aminosalicylic acid in normal subjects and in patients with colitis. $\mathrm{Br} \mathrm{J}$ Pharmacol 1984;17:474-6.

4. Rasmussen SN, Bondesen S, Hvidberg EF, et al. 5-Aminosalicylic acid in a slow release preparation: Bioavailability, plasma level and excretion in humans. Gastroenterology 1982;83:1062-70.

5. Das KM, Eastwood MA, McManus JPA, Sircus W. The metabolism of salicylazosulphapyridine in ulcerative colitis. Gut 1973;14:631-41.

6. Calder IC, Funder CC, Green CR. Nephrotoxic lesions from 5 -aminosalicylic acid. Br Med J 1972;1:152-4.

7. Novis BH, Korzets Z, Chen P, Bernheim J. Nephrotic syndrome after treatment with 5-aminosalicylic acid. Br Med J 1988;1:1442.
8. Calder IC, Williams PJ, Woods RA, et al. Nephrotoxicity and molecular structure. Xenobiotica 1975;5:303-7.

9. Riley SA, Mani V, Goodman MJ, Herel ME, Dutt S. Comparison of delayed release 5-aminosalicylic acid (mesalazine) and sulphasalazine in the treatment of mild to moderate ulcerative colitis relapse. Gut 1988;29:669-74.

10. Myers B, Evans DNW, Rhodes J. Metabolism and urinary excretion of 5 . aminosalicylic acid in healthy volunteers when given intravenously or released for absorption at different sites in the gastrointestinal tract. Gut 1987;28:196-200.

11. Nielsen OH, Bondesen S. Kinetics of 5-aminosalicylic acid after jejunal instillation in man. Br J Clin Pharmacol 1983;16:738-40.

12. Bossi A, Guiliani GE, Del Poggio P, Fenili D, Rajaini SS. Uncoated versus coated 5-aminosalicylic acid in Crohn's disease. Lancet 1989;i:276. 


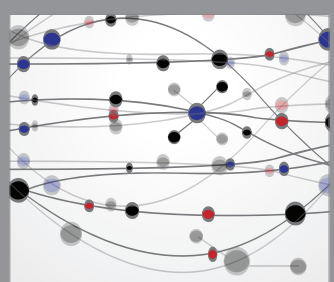

The Scientific World Journal
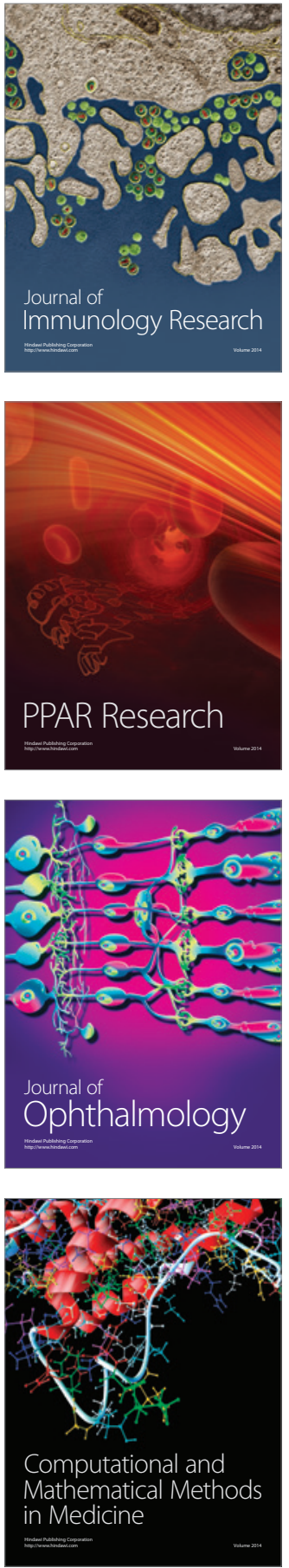

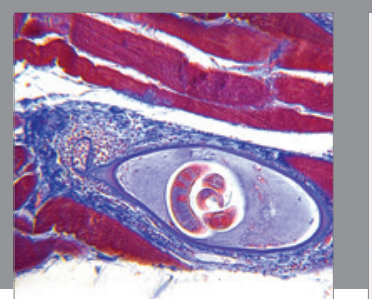

Gastroenterology Research and Practice

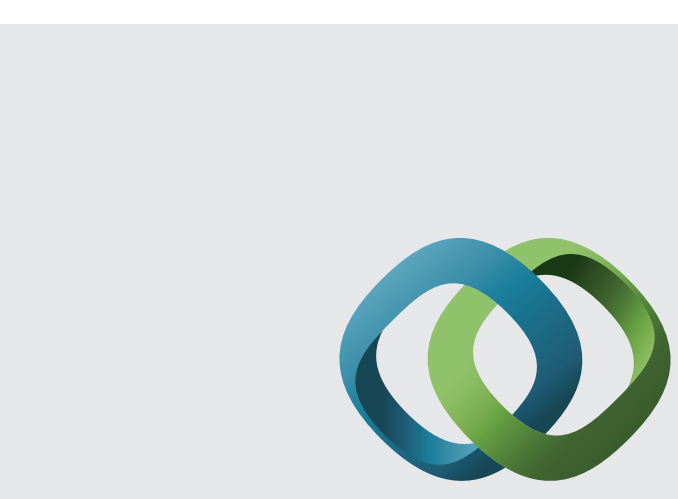

\section{Hindawi}

Submit your manuscripts at

http://www.hindawi.com
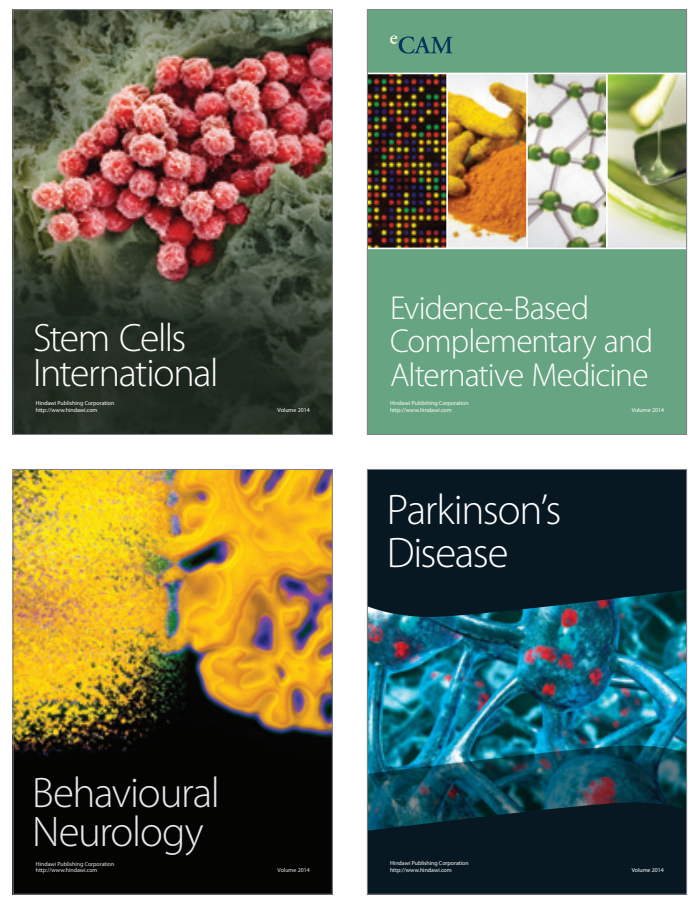
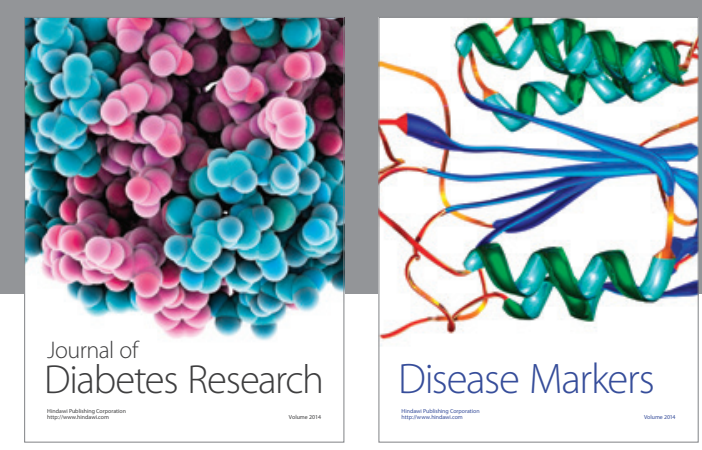

Disease Markers
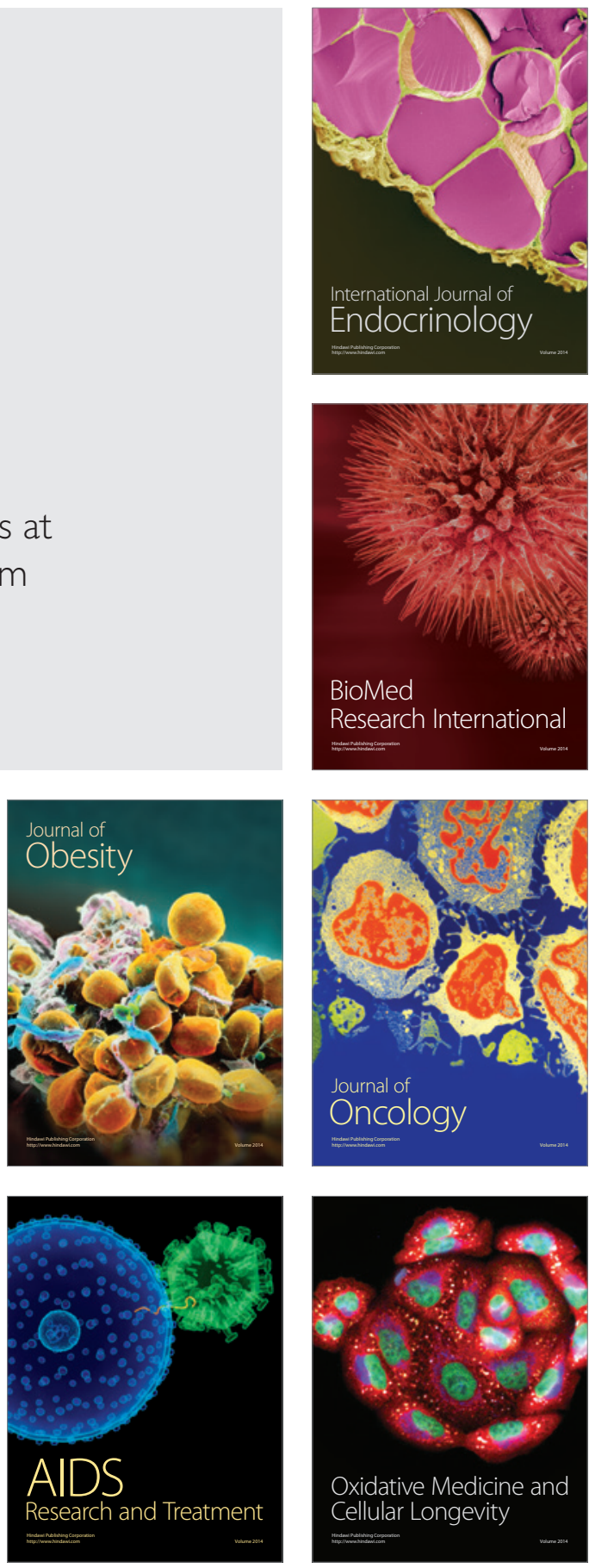